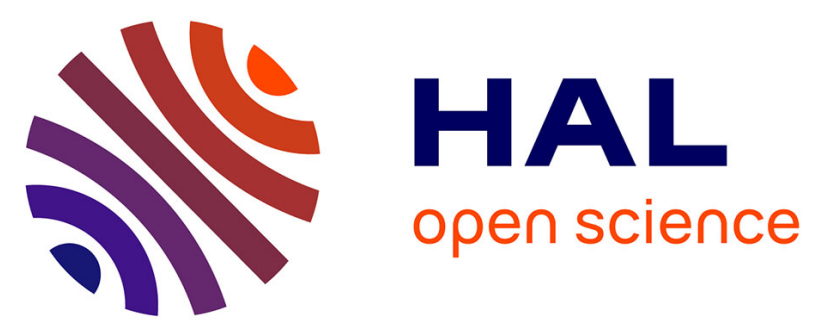

\title{
Antidiabetic sulfonylureas: localization of binding sites in the brain and effects on the hyperpolarization induced by anoxia in hippocampal slices
}

Christiane Mourre, Yehezkel Ben Ari, Henri Bernardi, Michel Fosset, Michel Lazdunski

\section{To cite this version:}

Christiane Mourre, Yehezkel Ben Ari, Henri Bernardi, Michel Fosset, Michel Lazdunski. Antidiabetic sulfonylureas: localization of binding sites in the brain and effects on the hyperpolarization induced by anoxia in hippocampal slices. Brain Research, 1989, 486 (1), pp.159-164. 10.1016/00068993(89)91288-2 . hal-02728227

\section{HAL Id: hal-02728227 \\ https://hal.inrae.fr/hal-02728227}

Submitted on 2 Jun 2020

HAL is a multi-disciplinary open access archive for the deposit and dissemination of scientific research documents, whether they are published or not. The documents may come from teaching and research institutions in France or abroad, or from public or private research centers.
L'archive ouverte pluridisciplinaire HAL, est destinée au dépôt et à la diffusion de documents scientifiques de niveau recherche, publiés ou non, émanant des établissements d'enseignement et de recherche français ou étrangers, des laboratoires publics ou privés. 


\title{
Antidiabetic sulfonylureas: localization of binding sites in the brain and effects on the hyperpolarization induced by anoxia in hippocampal slices
}

\author{
Christiane Mourre ${ }^{1}$, Yehezkel Ben Ari $^{2}$, Henri Bernardi ${ }^{1}$, Michel Fosset ${ }^{1}$ and \\ Michel Lazdunski ${ }^{1}$ \\ ${ }^{\prime}$ Centre de Biochimie, Centre National de la Recherche Scientifique, Nice (France) and ${ }^{2}$ Unité de Neurobiologie et Physiopathologie \\ du Développement, INSERM U.29, Hôpital de Port-Royal, Paris (France)
}

(Accepted 10 January 1989)

Key words: Adenosine triphosphate-sensitive $\mathrm{K}^{+}$channel; Autoradiography; Intracellular recording; Rat

\begin{abstract}
The distribution of antidiabetic sulfonylurea $\left(\left[{ }^{3} \mathrm{H}\right]\right.$ glibenclamide) binding sites is heterogeneous in rat brain. Pyramidal and extrapyramidal motor system contain the highest densities of sites, particularly in the substantia nigra and in the globus pallidus. Only low levels are present in the hypothalamic nuclei and the main medulla oblongata regions. In hippocampal formation the stratum lucidum and the stratum lacunosum moleculare of CA3 show an important density of glibenclamide binding sites. Electrophysiological studies with hippocampal slices show that glibenclamide blocks hyperpolarization induced by anoxia, suggesting the involvement of adenosine triphosphate-sensitive $\mathrm{K}^{+}$channel in this early hyperpolarization event.
\end{abstract}

Sulfonylureas form an important class of widely used antidiabetic drugs which stimulate insulin secretion in pancreatic $\beta$-cells ${ }^{1}$. Their target is the adenosine triphosphate (ATP)-sensitive $\mathrm{K}^{+}$channel $^{19,23}$. Glibenclamide is presently the most potent molecule in the sulfonylurea series $\left(K_{\mathrm{d}}=0.3-0.7\right.$ $\mathrm{nM}) .\left[{ }^{3} \mathrm{H}\right]$ glibenclamide has been shown to be a good ligand to characterize sulfonylurea binding sites in cerebral cortex microsomes ${ }^{6,12}$.

The activation of $\mathrm{K}^{+}$plays an important role in anoxia. Anoxia of hippocampal neurons produces an early hyperpolarization which is due to the activation of $\mathrm{K}^{+}$channels and a rapid blockade of synaptic transmission ${ }^{5,7,10,13,14}$.

In the present study, we describe the distribution of $\left[{ }^{3} \mathrm{H}\right]$ glibenclamide receptors in the brain and particularly in the hippocampus which is the brain area most sensitive to ischemic damage ${ }^{21}$. We also report that glibenclamide blocks the early hyperpolarization produced by hypoxia in hippocampal slices, suggesting that the ATP-sensitive $\mathrm{K}^{+}$channels may play a role in the electrical events leading to a blockade of synaptic transmission during anoxia.

Adult rat brain microsomes ${ }^{16}(0.95 \mathrm{mg} / \mathrm{ml})$ were incubated for $60 \mathrm{~min}$ (equilibrium binding was found to be reached at $40 \mathrm{~min}$ ) at $4{ }^{\circ} \mathrm{C}$ in $20 \mathrm{mM}$ $\mathrm{HEPES} / \mathrm{NaOH}$ buffer at $\mathrm{pH} 7.5$ with the required concentrations of $\left[{ }^{3} \mathrm{H}\right]$ glibenclamide $(50 \mathrm{Ci} / \mathrm{mmol}$, $99 \%$ pure). Incubations were stopped by rapid filtration through Whatman GF/B filters under reduced pressure. Filters were washed with $100 \mathrm{mM}$ Tris/ $\mathrm{HCl}$ buffer at $\mathrm{pH} 7.5$ and $4{ }^{\circ} \mathrm{C}$ and counted. Non-specific binding was measured using $0.1 \mu \mathrm{M}$ glibenclamide. $\left[{ }^{3} \mathrm{H}\right]$ Glibenclamide binding was proportional to membrane protein concentrations between 0.2 and $1.3 \mathrm{mg} / \mathrm{ml}$ and was found to be unaffected by changes of ionic strength up to $1 \mathrm{M}$ $\mathrm{NaCl}$. Rat brain sections of $15 \mu \mathrm{m}$ thickness were prepared as described ${ }^{17}$ and incubated with $0.02-3$ $\mathrm{nM}\left[{ }^{3} \mathrm{H}\right]$ glibenclamide (for autoradiographic procedures, $2.5 \mathrm{nM}\left[{ }^{3} \mathrm{H}\right]$ glibenclamide) as described above. Sections were washed at the end of the

Correspondence: C. Mourre, Centre de Biochimie, Centre National de la Recherche Scientifique, Parc Valrose, 06034 Nice Cedex, France. 

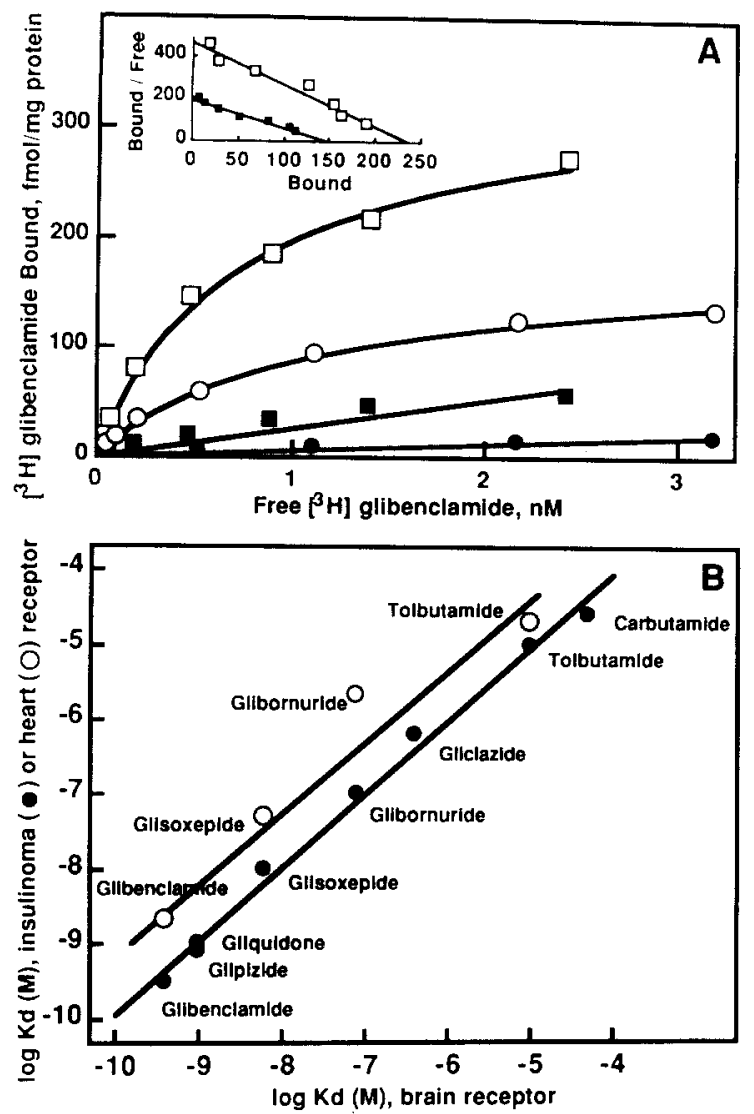

Fig. 1. Binding of $\left[{ }^{3} \mathrm{H}\right]$ glibenclamide to rat brain microsomes and to rat brain sections. A: binding to microsomes in the absence $(O)$ or in the presence of $0.1 \mu \mathrm{M}$ glibenclamide $(0)$ and to brain sections, in the absence $(\square)$ or in the presence ( $\square$ ) of $1 \mu \mathrm{M}$ glibenclamide. Inset: Scatchard plot for the specific $\left[{ }^{3} \mathrm{H}\right]$ glibenclamide binding. Microsomes $(\boldsymbol{E})$, sections $(\square)$. B: binding of $\left[{ }^{3} \mathrm{H}\right]$ glibenclamide to microsomes from rat brain, from insulinoma, and from guinea pig hearts. Correlation curve. $K_{\mathrm{d}}$ values of different sulfonylureas for binding to rat brain microsomes were plotted versus $K_{\mathrm{d}}$ values of different sulfonylureas for binding to insulinoma cell (RINm5F) microsomes $^{3}$ (slope $=0.98, r=0.99$ ) or to guinea pig heart microsomes ${ }^{9}$ (slope $=0.98 ; r=0.99$ ). Both experiments were done in duplicate.

incubation. Some sections were removed and counted. The other slices were used to prepare autoradiograms ${ }^{17}$. The films were analyzed and quantified using a computerized image analysis system $^{17}$. For electrophysiological studies, conventional hippocampal slices were prepared from adult male Wistar rats and maintained fully submerged in vitro ${ }^{3}$.

Sulfonylurea binding sites are present in mammalian brain membranes and can be identified with $\left[{ }^{3} \mathrm{H}\right]$ glibenclamide. Fig. $1 \mathrm{~A}$ shows comparative equi- librium binding of $\left[{ }^{3} \mathrm{H}\right]$ glibenclamide to rat brain microsomes and to brain sections. Scatchard plots indicate the presence of a single type of high affinity saturable binding sites with equilibrium dissociation constant, $K_{\mathrm{d}}=0.7 \pm 0.1 \mathrm{nM}$ for microsomes and $K_{\mathrm{d}}$ $=0.5 \pm 0.1 \mathrm{nM}$ for brain sections (Fig. 1A, inset). Binding capacities $\left(B_{\max }=140 \pm 10 \mathrm{fmol} / \mathrm{mg}\right.$ of protein) for brain microsomes are comparable to those ( $150 \mathrm{fmol} / \mathrm{mg}$ of protein) found for insulinoma microsomes ${ }^{19}$. Specific $\left[{ }^{3} \mathrm{H}\right]$ glibenclamide binding to rat brain microsomes was inhibited by glibenclamide and other sulfonylureas (not shown). An excellent correlation was observed between affinities of different sulfonylureas for their binding sites in rat brain membranes, in insulinoma cell (RINm5F) membranes and in cardiac cell microsomes (Fig. 1B). This is an important observation since these binding sites have clearly been shown to be associated with ATP-sensitive $\mathrm{K}^{+}$channels both in insulinoma cells ${ }^{19}$ and in cardiac cells ${ }^{4}$.

Fig. 2 shows the distribution of $\left[{ }^{3} \mathrm{H}\right]$ glibenclamide binding sites in rat brain using a quantitative autoradiographic procedure. The localization of glibenclamide binding sites was very heterogeneous. The 5 main structures containing the highest concentrations of receptors were the substantia nigra, the globus and ventral pallidus, the motor neocortex and the molecular layer of the cerebellar cortex. All these structures participate in the pyramidal and extrapyramidal motor control. The other motor regions presented intermediate densities of binding sites. In the somatosensory system, except for the sensory neocortex the majority of sensory relays contained intermediate to low densities of sulfonylurea binding sites. The hypothalamic nuclei, the reticular formation and most areas of the medulla oblongata were poor in glibenclamide sites. Specific binding was undetectable in fiber tracts. In the limbic system, the septohippocampal nucleus was very enriched in glibenclamide binding sites, while low densities were present in accumbens nucleus, habenula and mammillary bodies. In the hippocampus, the highest level of binding sites was found in stratum lucidum of CA3 where the mossy fibers make synaptic contacts with the proximal part of the apical dendrite of CA3 neurons (Fig. 3). The lacunosum moleculare presented high densities in $\mathrm{CA} 3$ and intermediate densities in CA1 and CA2. 
Intermediate levels of binding were found in stratum oriens (CA1-CA3) and low levels of binding in stratum radiatum (CA1-CA3). In the dentate gyrus, the hilus, the granular layer and the external molecular layer contained an important level of sites. An intermediate density was found in the internal molecular layer. Glibenclamide binding sites could, in principle, be present in neuronal and neuroglial cells, but no specific binding was detectable in astrocytes in culture (not shown), suggesting a neuronal localization of the receptors.

The presence of sulfonylurea receptors in the brain suggests the associated presence of ATPsensitive $\mathrm{K}^{+}$channels. These channels have been directly identified by patch-clamp techniques with neuronal cells from rat cortex in culture ${ }^{2}$. Since ATP-sensitive $\mathrm{K}^{+}$channels seem to be involved in electrical events associated with cardiac ischemia ${ }^{4}$, 11.18 .22 , it also seems logical to associate them with early electrical events associated with brain ischemia. The rapid loss of awareness and purposive behavior of man and higher animals when the brain oxygen supply is cut off, is a universally-known phenomenon. The exact cellular mechanisms of this loss are still largely unexplained. However, it has been suggested by Krnjevic ${ }^{13}$ that the tight coupling between consciousness, neuronal activity and oxygen supply might be mediated by a change in $\mathrm{K}^{+}$

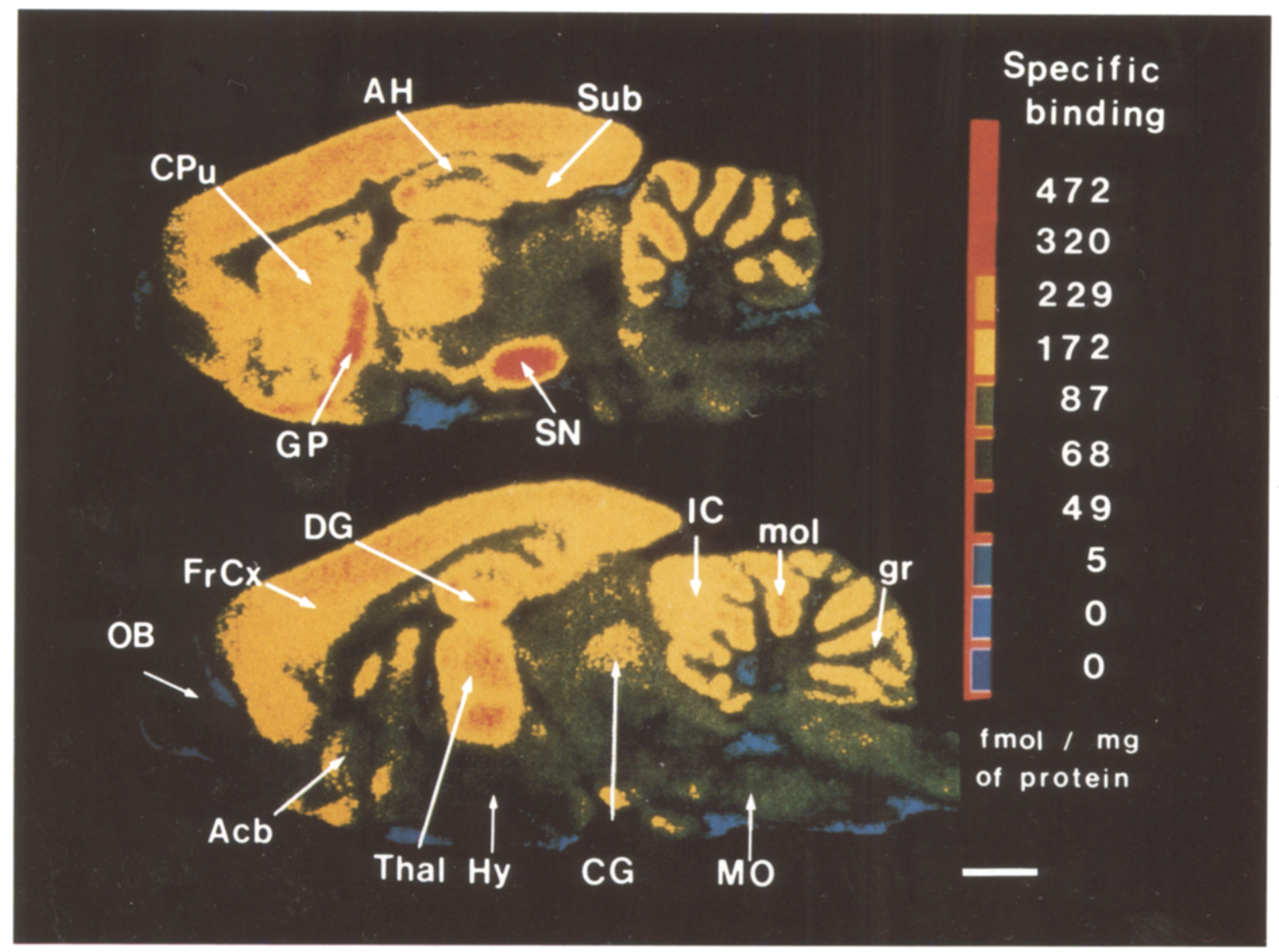

Fig. 2. Color image analysis of the autoradiographic distribution of $\left[{ }^{3} \mathrm{H}\right]$ glibenclamide binding sites in rat brain. The color scale corresponds to the specific binding expressed in $\mathrm{fmol} / \mathrm{mg}$ of protein. Brain sections were incubated in $2.5 \mathrm{nM}\left[{ }^{3} \mathrm{H}\right] \mathrm{glibenclamide}$ as described in Fig. 1. The non-specific binding was identical to the background of the tritium-sensitive film (not shown). Acb, accumbens nucleus; AH, Ammon's horn; CG, central gray; CPu, caudate putamen; DG, dentate gyrus; FrCx, frontal cortex; Gp, globus pallidus; Gr, granular layer of the cerebellar cortex; Hy, hypothalamus; IC, inferior colliculus; Mo, medulla oblongata; mol, molecular layer of the cerebellar cortex; OB, olfactory bulb; SN, substantia nigra; Sub, subiculum; Thal, thalamus. Bar = 2 mm. 

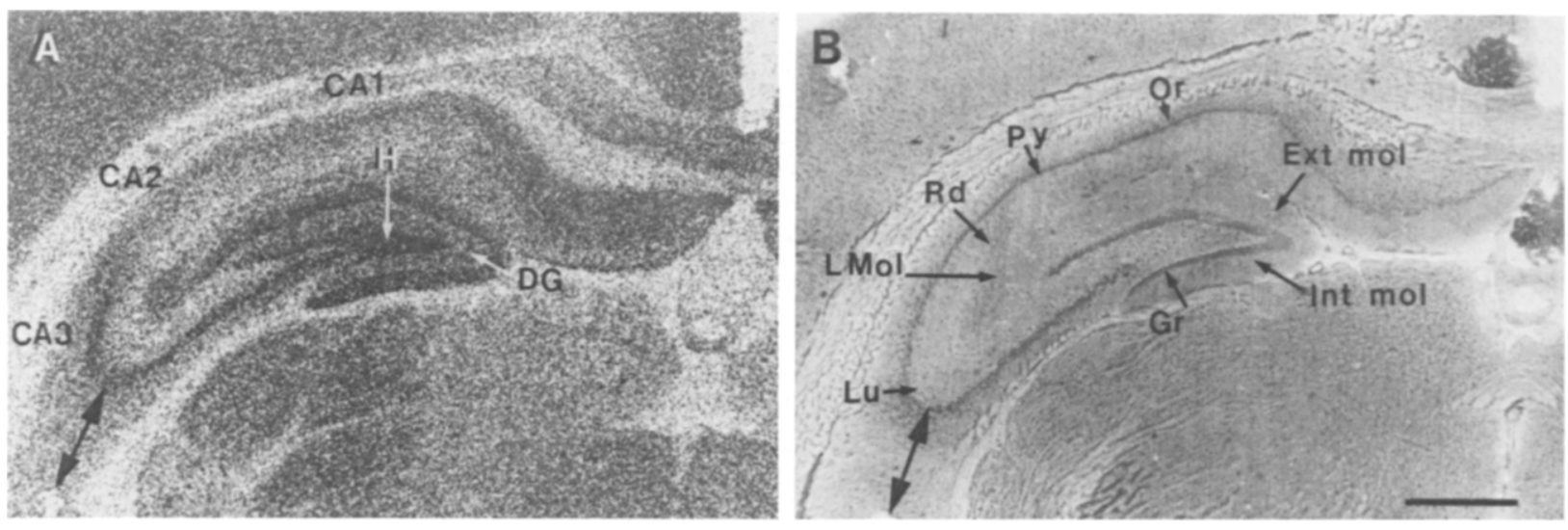

Fig. 3. Autoradiographic distribution of $\left[{ }^{3} \mathrm{H}\right]$ glibenclamide binding sites in the rat hippocampal formation. Dark areas indicate high levels of binding sites. The autoradiogram (A) corresponded to the histological micrograph (B). The double arrow was used as a guide mark to observe the very high labelling of the mossy fiber fields in CA3. Brain sections were incubated in $2.5 \mathrm{nM}$ $\left[{ }^{3} \mathrm{H}\right]$ glibenclamide. CA1,2,3, regions 1,2,3 of Ammon's horn; DG, dentate gyrus; Ext mol, external molecular layer; Gr. granular layer; $\mathrm{H}$, hilus; Int mol, internal molecular layer; LMol, stratum lacunosum moleculare; Lu, stratum lucidum; Or, stratum oriens; Py, stratum pyramidal; $\mathrm{Rd}$, stratum radiatum. Bar $=1 \mathrm{~mm}$.

conductance. This suggestion is now strengthened by numerous observations that anoxia has a hyperpolarizing effect on neocortical and hippocampal neurons $s^{5,7,10}$. The early hyperpolarizing step has been first suggested to be due to an activation of $\mathrm{Ca}^{2+}$-sensitive $\mathrm{K}^{+}$channels ${ }^{13}$, but it has also been thought to be due to ATP-sensitive $\mathrm{K}^{+}$channels ${ }^{5}$. These channels would be expected to be activated in parallel with the decrease of intracellular ATP concentration following acute anoxia. Glibenclamide which blocks ATP-sensitive $\mathrm{K}^{+}$channels should then be expected to prevent anoxia-induced hyperpolarization.

In agreement with earlier studies ${ }^{5,7,10,13,14}$, a brief anoxic episode (2-3 $\mathrm{min}$ ) produced in CA3 neurons a small depolarization followed by an hyperpolarization associated with a reduction in input resistance. Upon return to oxygenated medium there was a post-anoxic hyperpolarization which is thought to be due to the reactivation of the electrogenic $\mathrm{Na}^{+}$ pump (Fig. 4A and also refs. 5, 7, 10, 14). Bath application of glibenclamide $(0.5-1 \mu \mathrm{M})$ produced a block of the early hyperpolarization and a considerable increase of the post-anoxic hyperpolarization (Fig. 4B); both effects were reversible (Fig. 4C). Interestingly, in the presence of glibenclamide, the anoxic episode was often associated with a larger increase in synaptic activity and a larger decrease in input resistance (Fig. 4B). Similar observations were
A

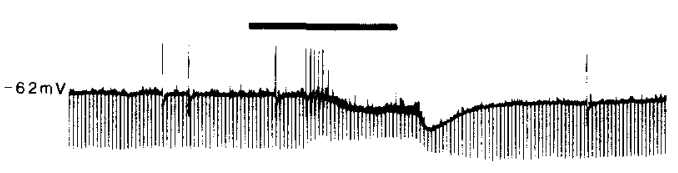

B

Glib $(1 \mu \mathrm{M})$

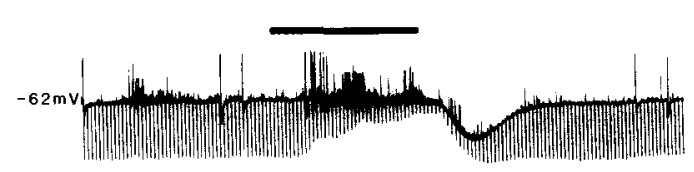

c

Wash

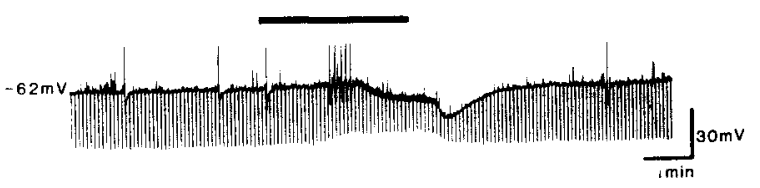

Fig. 4. Glibenclamide blocks the early hyperpolarization produced by a brief anoxic episode. Three brief anoxic episodes ( 3 min dark bar) were applied while recording intracellularly the same CA3 neuron. In control (A) as during 12-min wash (C), anoxia induced an early hyperpolarization associated with a reduction in input resistance as tested by electronic potentials induced by hyperpolarizing constant current pulses through the recording electrode. Upon return to oxygenated medium there was an additional late hyperpolarization. (B) The early hyperpolarization was fully blocked in the presence of glibenclamide. Also in the presence of glibenclamide, there was an increase in the synaptic activity during anoxia and the postanoxic hyperpolarization was enhanced. 
made in 5 CA 3 neurons; in 4 of these neurons, bath application of glibenclamide in control oxygenated medium had no effects on membrane potential or resistance. This suggests that the effects of the drug may involve ATP-sensitive $\mathrm{K}^{+}$channels which, as in cardiac cells, are probably silent in physiological intracellular ATP concentrations. The enhanced synaptic activity and resistance decrease seen in the presence of glibenclamide may be due to a presynaptic effect of the drug which by blocking ATPdependent $\mathrm{K}^{+}$channels during anoxia would enhance transmitter release.

In contrast to the present observations, Krnjevic and Leblond ${ }^{15}$ have recently reported that in the CA1 region the other sulfonylurea tolbutamide does not reduce the anoxic hyperpolarization. This discrepancy may be due to regional differences in the distribution of ATP-dependent $\mathrm{K}^{+}$channels.

Interstitial $\mathrm{K}^{+}$concentrations drastically increase in brain cortex after cardiac arrest. This increase occurs in two major phases. In the first one $(\sim 2$ $\mathrm{min}),\left[\mathrm{K}^{+}\right]_{\mathrm{o}}$ increases from normal to $\sim 10 \mathrm{mM}$. In the following second phase, there is a steep (a few seconds) increase of $\left[\mathrm{K}^{+}\right]_{\mathrm{o}}$ to concentrations as high as $60 \mathrm{mM}$. This second phase is associated with extensive cellular $\mathrm{Ca}^{2+}$ uptake leading ultimately to

1 Ashcroft, F.M., Adenosine 5 -triphosphate-sensitive potassium channels, Ann. Rev. Neurosci., 11 (1988) 97-118.

2 Ashford, M.L.J., Sturgess, N.C., Trout, N.J., Gardner, N.J. and Hales, C.N., Adenosine 5 'triphosphate-sensitive ion channels in neonatal rat cultured central neurons, Pflügers Arch., 412 (1988) 297-304.

3 Cherubini, E., Ben Ari Y., Gho, M., Bidard, J.-N. and Lazdunski, M., Long-term potentiation of synaptic transmission in the hippocampus induced by a bee venom peptide, Nature (Lond.), 328 (1987) 70-73.

4 Fosset, M., De Weille, J.R., Green, R.D., SchmidAntomarchi, H. and Lazdunski, M., Antidiabetic sulfonylureas control action potential properties in heart cells via high affinity receptors that are linked to ATP-dependent $\mathrm{K}^{+}$channels, J. Biol. Chem., 263 (1988) 7933-7936.

5 Fujiwara, N., Higashi, H., Shimoji, K. and Yoshimura, M., Effects of hypoxia on rat hippocampal neurons in vitro, J. Physiol. (Lond.), 384 (1987) 131-151.

6 Geisen, K., Hitzel, V., Okomonopoulos, R., Pünter, J., Weyer, R. and Summ, H.D., Inhibition of $\left[{ }^{3} \mathrm{H}\right]$ glibenclamide binding to sulfonylurea receptors by oral antidiabetics, Arzneim-Forsch. Drug Res., 35 (1985) 707 712 .

7 Glötzner, F., Intrazelluläre Potentiale, EEG und korticale Gleichspannung an der sensomotorischen Rinde der Katze bei akuter Hypoxie, Archiv. Psychiatr., 210 (1967) 274296. cell death particularly in hippocampus ${ }^{9,20}$. It appears possible that the first phase of $\mathrm{K}^{+}$efflux from neuronal cells might be due to $\mathrm{K}^{+}$release through open ATP-sensitive $\mathrm{K}^{+}$channels, since this phase has been found to be shortened in hypoglycemic animals (lower blood glucose and presumably lower intracellular ATP concentrations) and considerably prolonged in hyperglycemic animals (higher blood glucose and presumably higher intracellular ATP concentrations) $)^{8,9}$.

We are grateful to Dr. E. Cherubini for his remarks, to Hoechst-Roussel Pharmaceuticals, Boehringer Ingelheim, Hoffmann-La Roche, Schering, and Laboratoires Servier for generous gifts of glibenclamide, $\left[{ }^{3} \mathrm{H}\right]$ glibenclamide, tolbutamide, gliquidone, glibornuride, glisoxepide, carbutamide and gliclazide. We thank Dr. J. Kitabgi for gifts of glipizide, and M.-T. Bohn, C. Widmann, C. Roulinat-Bettelheim and $F$. Aguila for expert assistance. Supported by the Centre National de la Recherche Scientifique, the Fondation pour la Recherche Médicale, the Institut National de la Santé et de la Recherche Médicale (Grant CRE 88.2007), and the Mutuelle Générale de l'Education Nationale.

8 Hansen, A.J., The extracellular potassium concentration in brain cortex following ischemia in hypo- and hyperglycemic rats, Acta Physiol. Scand., 102 (1978) 324-329.

9 Hansen, A.J., Effect of anoxia on ion distribution in the brain, Physiol. Rev., 65 (1985) 101-148.

10 Hansen, A.J., Hounsgaard, J. and Jahnsen, H., Anoxia increases potassium conductance in hippocampal nerve cells, Acta Physiol. Scand., 115 (1982) 301-310.

11 Kakei, M., Noma, A. and Shibasaki, T., Properties of adenosine-triphosphate-regulated potassium channels in guinea pig ventricular cells, J. Physiol. (Lond.), 363 (1985) 441-462.

12 Kaubisch, N., Hammer, R., Wollheim, C., Renold, A.E. and Offord, R.E., Specific receptors for sulfonylureas in brain and in a $\beta$ cell tumor of the rat, Biochem. Pharmacol., 31 (1982) 1171-1174.

13 Krnjevic, K., Coupling of neuronal metabolism and electrical activity. In D.H. Ingvar and N.A. Lassen (Eds.), Brain Work, Munksgaard, Copenhagen, 1975, pp. 65-78.

14 Krnjevic, K. and Leblond, J, , Anoxia reversibly suppresses neuronal calcium currents in rat hippocampal slices, Can. J. Physiol. Pharmacol., 65 (1987) 2157-2161.

15 Krnjevic, K. and Leblond, J., Are there hippocampal ATP-sensitive $\mathrm{K}$ channels that are activated by anoxia? Eur. J. Physiol., 411 (1988) R145.

16 Krueger, B.K., Ratzlaff, R.W., Strichartz, G.R. and Blaustein, M.D., Saxitoxin binding to synaptosomes, mem- 
branes and solubilized binding sites from rat brain, $J$. Memb. Biol., 50 (1979) 287-310.

17 Mourre, C., Hugues, M. and Lazdunski, M., Quantitative autoradiographic mapping in rat brain of the receptor of apamin, a polypeptide toxin specific for one class of $\mathrm{Ca}^{2+}$-dependent $\mathrm{K}^{+}$channels, Brain Research, 382 (1986) 239-249.

18 Noma, A., ATP-regulated $\mathrm{K}^{+}$channels in cardiac muscle, Nature (Lond.), 305 (1983) 147-148.

19 Schmid-Antomarchi, H., De Weille, J.R., Fosset, M. and Lazdunski, M., The receptor for antidiabetic sulfonylureas controls the activity of the ATP-modulated $\mathrm{K}^{+}$channel in insulin-secreting cells, J. Biol. Chem., 262 (1987) 15840-
15844.

20 Siesjö, B.K., Historical overview. Calcium, ischemia and death of brain cells, Ann. N.Y. Acad. Sci., 522 (1988) 638-661.

21 Smith, M.L., Auer, R.N. and Siesjö, B.K., The density and distribution of ischemic brain injury in the rat following two to ten minutes of forebrain ischemia, Acta Neuropathol. (Berlin), 64 (1984) 319-332.

22 Stanfield, P.R., Nucleotides such as ATP may control the activity of ion channels, TINS, 10 (1987) 335-339.

23 Sturgess, N.C., Ashford, M.L.J., Cook, D.L. and Hales, C.N., The sulfonylurea receptor may be an ATP-sensitive potassium channel, Lancet, 2 (1985) 474-475. 